\title{
INTRODUCING E-LEARNING 2.0 IN SME A Practical Guide
}

\author{
Ileana Hamburg \\ Institut Arbeit und Technik, FH Gelsenkirchen, Munscheidst, 14, 45886 Gelsenkirchen, Germany \\ hamburg@iat.eu
}

\begin{abstract}
Keywords: e-Learning 2.0, SME, Strategies, Guide.
Abstract: e-Learning 2.0 can support corporate training to assure a fast transfer of knowledge by meeting small and medium sized-companies (SME) needs of flexibility, to be oriented to their business and be easier integrated into their workflow with a suitable personalized content at a lower cost to the organization. In this paper after the presentation of some reasons of the low use of e-Learning in European SMEs examples of training strategies including e-Learning 2.0 for improving this situation and guidelines to use them are given.
\end{abstract}

\section{INTRODUCTION}

e-Learning through its flexibility and facility of access is seen as an enabler of lifelong learning having the potential to transform how and when employees learn to satisfy their work and life needs, as a catalyst of change and integration. It is to be seen as a chance for small and medium-sized enterprises (SMEs) to improve their business and to integrate into the European market, too.

Research carried out in different European and national studies and projects (Atwell et al., 2003) shows that there is not much e-Learning going on SMEs and most of the few activities are of rather poor quality referring knowledge management. Most of the aspects presented in this paper are results of the research work and discussions with experts carried out in the context of the European project ARIEL - Analysing and Reporting the Implementation of e-Learning in Europe (www.ariel-eu.net), a project within the eLearning initiative (Beer et al., 2006; Hamburg and Lindecke, 2004, 2005). Within ARIEL 842 e-Learning projects have been analyzed and results have been structured.

These studies and projects show that the low use of e-Learning in European SMEs is due also to a lack of "long-term" vocational strategies including e-Learning based on qualification needs and on new technological developments.

In this paper after a presentation of some causes for low use of e-Learning within European SMEs and of e-Learning strategies, a practical guide for introducing it in SMEs is given. Particularly the com- bination of e-Learning with Web 2.0 (e-Learning 2.0) for achieving nowadays expectations of corporate learning to deliver enterprise services through the Web and for improving collaboration and effectiveness of work is recommended. "The challenge will not be in how to learn, but in how to use learning to create something more, to communicate."(Downes, 2005). This guide is in development in a community of practice within the ongoing eLearning project SIMPEL-Improving e-Learning in SMEs (www.simpel-eu.net). Adapted versions of the guide for each project partner country will be tested this year within SMEs from these countries. The guide can be used by SME managers, responsible with continuous education, consultants, etc. (Hamburg and Engert, 2007).

\section{EUROPEAN SMES, E-LEARNING AND THE USE OF THE WEB 2.0}

Small and medium-sized enterprises are socially and economically important, since they represent $99 \%$ of all enterprises in the EU, provide around 65 million jobs and contribute to entrepreneurship and innovation.

Significant international social and economic changes like globalisation, market competition, technological innovation and, particularly the European enlargement affect the situation of SMEs.

Many European SMEs have: 
- difficulties with management missing elements of knowledge management,

- low transfer of knowledge to improve the effectiveness of their work tasks,

- not enough knowledge of policies of communication and cooperation in research and production.

Also the use of new information and communication technologies (ICT) for sharing and creating knowledge and for development (updating) of innovative skills is unsatisfactory.

All these aspects require an improving of corporate learning to assure a fast transfer of knowledge, to allow SMEs to meet their needs of flexibility, to be oriented to their business and be easier integrated into their workflow with a suitable personalized content at a lower cost to the organization.

e-Learning 2.0 tools give a natural support for personal and group informal learning by simplifying also tasks like research, working and learning in groups. For example writing in public blogs forces to think about the corresponding issues. By putting this out to a community, input from peers and help from a network of individuals to learn and solve problems in the future will be received.

e-Learning 2.0 makes an impact also in formal learning settings and these are particularly useful for collaborative formal learning. e-Learning 2.0 is based on tools that combine creation of content easily with Web delivery and collaboration. Karrer's concept of e-Learning 2.0 (http://www.learningcircuits. org/2007/0707karrer.html) is based on delivery of content in small pieces over time as part of a large process which correspond to the needs of SME staff for a faster learning in the context of their work.

Results of studies and projects show some causes of the low use of e-Learning (also earlier Versions e-Learning 1.3 see Table 1) in SMEs:

- Training culture within the SMEs is often dependent on trainer and conventional training methods; skills needed for a more independent approach and the use of new media for learning are missing. SMEs managers have not enough knowledge or are not convinced of the effectiveness of e-Learning.

- The staff has a lack of time and motivation to test new learning methods.

- There is a lack of "long-term" vocational strategies for the staff based on deep analysis of their qualification needs. The most used learning strategies in SMEs are "learning by doing" and quickly informal methods.
- Appropriate software and contents for SMEs are missing. The major part of commercial eLearning software is modelled on the requirements of big enterprises or higher education and SMEs can not afford to pay tailor-made solutions. The existing training offers in supporting specific business needs of SMEs are often inadequate and unattractive. No personalized training facilities are integrated.

- A continuous cooperation between e-Learningdevelopers, -providers (e-Learning market) and SMEs which could improve this situation is missing.

Table 1: Generations of e-Learning.

\begin{tabular}{|c|c|c|c|}
\hline & 1.0 & 1.3 & 2.0 \\
\hline $\begin{array}{l}\text { Main } \\
\text { Components }\end{array}$ & $\begin{array}{l}\text { - Coursewa } \\
\text { re } \\
\text { - LMSs } \\
\text { - Authoring } \\
\text { tools }\end{array}$ & $\begin{array}{l}\text { - Reference } \\
\text { hybrids } \\
\text { - LCMSs } \\
\text { - Rapid } \\
\text { authoring } \\
\text { tools }\end{array}$ & $\begin{array}{l}\text { - Wikis } \\
\text { - Social } \\
\text { networking } \\
\text { and } \\
\text { bookmarking } \\
\text { tools } \\
\text { - Blogs } \\
\text { - Add-ins } \\
\text { - Mash-ups }\end{array}$ \\
\hline Ownership & $\begin{array}{l}\text { Top-down, } \\
\text { one-way }\end{array}$ & $\begin{array}{l}\text { Top-down, } \\
\text { collaborativ } \\
\text { e }\end{array}$ & $\begin{array}{l}\text { Bottom-up, } \\
\text { learner- } \\
\text { driven, } \\
\text { peer learning }\end{array}$ \\
\hline $\begin{array}{l}\text { Developmen } \\
\mathrm{t} \\
\text { time }\end{array}$ & Long & Rapid & None \\
\hline $\begin{array}{l}\text { Content } \\
\text { Size }\end{array}$ & 60 minutes & 15 minutes & 1 minute \\
\hline $\begin{array}{l}\text { Access } \\
\text { Time }\end{array}$ & $\begin{array}{l}\text { Prior } \\
\text { to work }\end{array}$ & $\begin{array}{l}\text { In between } \\
\text { work }\end{array}$ & During work \\
\hline $\begin{array}{l}\text { Virtual } \\
\text { Meetings }\end{array}$ & Class & $\begin{array}{l}\text { Intro, } \\
\text { office hours }\end{array}$ & Peers, Experts \\
\hline Delivery & $\begin{array}{l}\text { At one } \\
\text { time }\end{array}$ & $\begin{array}{l}\text { In many } \\
\text { pieces }\end{array}$ & $\begin{array}{l}\text { When you } \\
\text { need it }\end{array}$ \\
\hline $\begin{array}{l}\text { Content } \\
\text { access }\end{array}$ & LMS & $\begin{array}{l}\text { Email, } \\
\text { Intranet }\end{array}$ & $\begin{array}{l}\text { Search, } \\
\text { RSS feed }\end{array}$ \\
\hline Driver & ID & Learner & Worker \\
\hline $\begin{array}{l}\text { Content } \\
\text { creator }\end{array}$ & ID & SME & User \\
\hline
\end{tabular}

One possible solution presented in this paper and applied in our projects is to involve SMEs and e-Learning experts in sharing knowledge and in collaboration within a community of practice (Wenger et al., 2002; Busse et al., 2007) and to develop participative training strategies based on e-Learning 2.0. This form of learning is relatively new and requires more time to begin it and to take shape in most SMEs. It is expected that the eLearning solutions for SMEs will contain and combine aspects of each generation. 


\section{TRAINING STRATEGIES FOR SMES BASED ON E-LEARNING 2.0 AND CORRESPONDING GUIDE}

Based on the results of ARIEL and other projects, the European project SIMPEL started this year within eLearning initiative (http://www.simpelnet.eu). It is aimed at improving the e-Learning use in SMEs by participative development of sustainable e-Learning based training strategies and models. These strategies and models will be developed and disseminated including also good practices in e-Learning for SMEs. One of the activities within the project is the organization of workshops and seminars in all partner countries with representatives of SMEs, e-Learning developers and providers, trainers, e-Learning experts, regional authorities and researchers. The first meetings were used to discuss different e-Learning based training strategies and for searching ways to convince SMEs about the advantages of e-Learning.

Two general strategies for introducing e-Learning to be followed by the companies discussed on the German workshop within SIMPEL are the following (Kerres, 2001; Hamburg, 2007):

a) The strategy of minimal change e.g. introducing of new media and training concepts should involve only minimal changes in the structures and processes of the company. Through a latent implementation the acceptance of the new media by trainers will be assured and the staff is automatically introduced to the new tools and learning methods.

b) In contrast to the minimal change strategy active change includes a review of the organisation, its infrastructure, learning culture and business strategy as appropriate to the new learning objectives, concepts and methods.

For more efficiency, strategy b) should be followed. For reasons of acceptance often the starting point is, however, strategy a). Actors concerned with the introduction of e-Learning ought to be conscious of the fact that the minimal change approach may be suitable as long as e-Learning is seen as a first experiment. As soon as a serious commitment is made to e-Learning any conception has to rest on active change.

The following aspects are necessary in developing a strategy for implementing e-Learning, if it is going to be sustainable:
1. Identification of needs and Objectives of Training: While this is a truism for most training practitioners, SMEs very often hit their first serious barrier already here: Many SMEs do not have a Human Resource Department or a training expert to identify exactly the skills of the employees corresponding to the business objectives of the company. A need for training is often recognised only when a particular problem arises. So the owner of the SMEs should be helped to do this analysis in the wider context of business aims and longer term business planning, before the training process begins.

2. Engaging Employees: The literature suggests there are many barriers to employees undertaking e-Learning. Where e-Learning is linked very closely to day-to-day tasks, this is more successful.

3. Time Factors and Form of Training used: SMEs staffs are often guided by the daily business pressure and devote little time to learning activities. So they prefer informal forms of the learning taking place often on the job through sharing experience with colleagues about the job tasks.

4. Courses/Learning Content: The most important subject for training courses in SMEs should be the "core business" of the company and should refer to the competencies the staff need for their work tasks. Other subjects should be norms and procedures helping SMEs to survive/integrate into the market. But also management skills, accounting and language skills are important to be learned.

5. Tutor Support for e-Learning and integration of it with more Traditional Forms of Learning: The evidence suggests that the learning experience is better and completion rates are greater where there is tutor support either face to face, on-line or over the telephone.

6. Learning Infrastructures: space, time, clime, etc to support e-Learning.

7. Organisational Perspective, Transfer of Knowledge: community of practice, learning groups, partnerships supported by learning platforms and special connections have to be developed in order to strengthen dialogical transfer.

8. Economical Aspects: a business part of the model should represent economical aspects of the e-Learning strategy.

9. Quality and (self) Evaluation Criteria: Quality criteria have to be established. Evaluation tools for efficiency and results of the training efforts 
should be developed that can be easily handled because SMEs lack staff and know-how and do seldom some evaluation.

The following figure shows the steps for planning, developing and implementing e-Learning in SMEs.

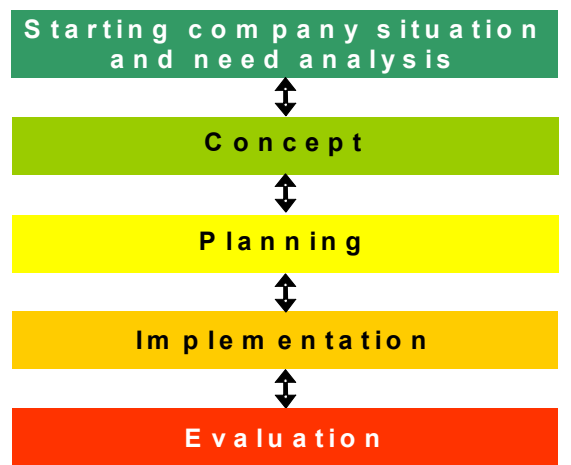

Figure 1: Steps for introducing e-Learning in SMEs.

Another method we experienced within the project ARIEL is the scenario building (Schoemaker 1991). Within SIMPEL we use scenarios in workshops with SMEs managers, staff and consultants to adopt Web 2.0 and how to combine elements of each e-Learning generation as part of their daily work. Web $2.0 \mathrm{can}$ be effectively used in SMEs for management (planning and formulating for strategies by using actual information, examples from competitors through professional bloggs with RSS Feeds, etc.), marketing (i.e. by using social networks like XING new clients can be found), production (i.e. to describe new products/services and to discuss their content by using Wiki or blogs) and purchase.

\section{CONCLUSIONS}

In order to work efficiently in new upcoming contexts, SMEs are required to improve their learning strategies. e-Learning particularly by using Web 2.0 can contribute to the achievement of needed competences for efficient work, can meet the pronounced needs for flexibility in SMEs, supports collaboration and personalized learning. It is important, however, to help SMEs to develop and to implement such training strategies based particularly on e-Learning 2.0 because many of them have not always the resources and knowledge to do this alone.

\section{REFERENCES}

Attwell, G., Dirckinck-Holmfeld, L., Fabian, P., Kárpáti, A. \& Littig, P., 2003. E-Learning in Europe - Results and Recommendations. Thematic Monitoring under the Leonardo Da Vinci Programme. Report. Impuls 010. Bonn.

Beer, D., Busse, T., Hamburg, I., Mill, U. \& Paul, H., 2006. e-learning in European SMEs: observations, analyses \& forecasting. Münster, Waxmann ISBN 38309-1631-0.

Busse, T., Hamburg, I. \& Engert, S., 2007. Improving collaboration and participation in E-Learning for SMEs by suitable models supported by virtual learning environments, presentation at the "Moodle 2007", March 28-29, 2007, University of Duisburg-Essen.

Downes, St., 2005. E-learning 2.0. http://elearnmag.org/ subpage.cfm? section $=$ articles\&article $=29-1$

Hamburg, I. \& Lindecke, Ch., 2004. E-Learning für kleine und mittlere Unternehmen: eine Untersuchung europäischer Projekte. In: Pangalos, J., Knutzen, S. \& Howe, F. (Eds.) Informatisierung von Arbeit, Technik und Bildung: Kurzfassung der Konferenzbeiträge; GTW-Herbstkonferenz, Oct. 4-5, 2004. Hamburg: Techn. University, 159-162.

Hamburg, I. \& Lindecke, Ch., 2005. Lifelong learning, e-learning and business development in small and medium enterprises. In: Szücs, A. \& Bo, I. (Eds.) Lifelong e-learning: bringing e-learning close to lifelong learning and working life; a new period of uptake: proceedings of THE EDEN 2005 Annual Conference, June 20-23, 2005, 79-84.

Hamburg, I. \& Engert, S., 2007. Competency-based Training in SMEs: The Role of E-Learning and ECompetence. In Proceedings of the 6th IASTED International Conference "Web-based Education", March 14-16, 2007, Chamonix, France. Anaheim: Acta Press, 189-193.

Hamburg, I. 2007. Shifting e-Learning in SMEs to a Workbased and Business Oriented Topic. In European Distance and E-Learning Network: New learning 2.0? Emerging digital territories-developing continuities new divides; THE EDEN Annual Conference 2007, June 13-16, 2007, Naples. CD-ROM. Budapest: EDEN, 4.

Kerres, M., 2001. Multimediale und telemediale Lernumgebungen. - Konzeption und Entwicklung. München, Oldenbourg.

Schoemaker, P.J.H, 1991. When and how to use scenario planning: A Heuristic Approach with Illustration. Journal of forecasting 10, pp. 594-564.

Wenger, E., McDermott, R. \& Sydner, W., 2002. Cultivativating communities of practice: a guide to managing knowledge. Boston: Harvard Business School Press. 